\title{
Article \\ FinTech in the Small Food Business and Its Relation with Open Innovation
}

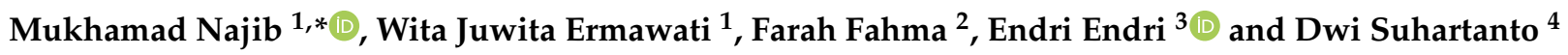 \\ 1 Department of Management, IPB University, Bogor 16680, Indonesia; witaman@apps.ipb.ac.id \\ 2 Department of Agroindustrial Technology, IPB University, Bogor 16680, Indonesia; \\ farah_fahma@apps.ipb.ac.id \\ 3 Department of Master Management Graduate Programs, Universitas Mercu Buana, Jakarta 11650, Indonesia; \\ endri@mercubuana.ac.id \\ 4 Department of Business Administration, Politeknik Negeri Bandung, Bandung 40012, Indonesia; \\ dwi.suhartanto@polban.ac.id \\ * Correspondence: najib@apps.ipb.ac.id
}

check for

updates

Citation: Najib, M.; Ermawati, W.J.; Fahma, F.; Endri, E.; Suhartanto, D. FinTech in the Small Food Business and Its Relation with Open

Innovation. J. Open Innov. Technol. Mark. Complex. 2021, 7, 88. https:// doi.org/10.3390/joitmc7010088

Received: 18 February 2021

Accepted: 4 March 2021

Published: 8 March 2021

Publisher's Note: MDPI stays neutral with regard to jurisdictional claims in published maps and institutional affiliations.

Copyright: (c) 2021 by the authors. Licensee MDPI, Basel, Switzerland. This article is an open access article distributed under the terms and conditions of the Creative Commons Attribution (CC BY) license (https:// creativecommons.org/licenses/by/ $4.0 /)$

\begin{abstract}
Small food businesses have difficulty accessing banks for financing. The growth of the sharing economy through financial technology (FinTech) makes it possible for small enterprises to receive access for credit. However, not all small business owners want to receive financing from FinTech companies. This study aims to analyze factors affecting FinTech adoption in small enterprises and its impact on business sustainability. The modified UTAUT 2 model was applied in this study. There were 184 small food business owners participating as respondents. To analyze the causal relationship between variables, Structural Equation Modeling (SEM) was implemented. The results of the research found that knowledge, safety perceptions, performance expectations, social influence, facilitation conditions and price values affect FinTech adoption by small food business owners. Moreover, FinTech adoption influences small food business sustainability. Several important recommendations for researchers, the FinTech industry and policy makers are formulated.
\end{abstract}

Keywords: FinTech; adoption; small food businesses; business sustainability; financing; Indonesia

\section{Introduction}

Small businesses have become an important part of economic activity in developing countries, especially in creating jobs and reducing poverty [1,2]. According to Abadli et al. [3], governments in developing countries recognize the important role of small and medium enterprises in national economic development. Moreover, small food businesses can contribute more for achieving Sustainable Development Goals (SDGs), namely zero hunger, environmental protection and providing safety in food [4,5]. However, small food businesses still face unfinished obstacles to growing and expanding their roles and contributions. Several problems that still exist in small business are financial limitation, a lack of technology and human capital [6]. In addition, small business owners still have limitations to access financing from the bank or other formal financial institutions [7-9].

Small and Medium Enterprises (SMEs) are estimated to contribute 55 percent of GDP to countries that are members of economic cooperation and development organizations, while employment opportunities provide 60 percent worldwide [9]. Therefore, the economic benefits of increasing SMEs' access to the financial sector can be very important [10]. The growth of financial technology (FinTech) business provides an opportunity for small food business owners to access financing and develop their business capacity [11]. One of the FinTech services that is currently growing rapidly is peer-to-peer (P2P) lending. In 2019 , the global P2P lending market size will be $\$ 67.93$, and by 2027 it is projected to reach $\$ 558.91$ billion with a compound annual growth rate (CAGR) of $29.7 \%$ from 2020 to 2027 [12]. In Indonesia, the growth of FinTech lending loans is projected at $214 \%$ over 2018-2020 [13]. 
P2P lending platforms can eliminate the need for banks to act as intermediaries, as they provide an online marketplace suitable for investors willing to lend with borrowers looking for loans [14]. Basically, P2P lending is not a new business model, since in traditional ways people were commonly implementing lending and borrowing without an intermediary $[15,16]$. However, in the era of the industrial revolution 4.0, P2P lending companies acted as intermediaries to facilitate investor interests with the desire to be borrowed to become feasible with FinTech. P2P lending in the industrial era 4.0 has taken advantage of digital technology, which allows simpler processes to reduce costs, enabling the use of electronic contracts; the diversification of investors to reduce credit risk; and the use of further information in credit scoring so that the credit disbursement process is also faster [16].

P2P lending as part of financial innovation has a positive impact on the operation and productivity of small business [16-18]. The most important role of FinTech is that FinTech can improve financial access for small businesses that cannot be covered by banks or other formal financial institutions $[19,20]$. FinTech is suitable for small businesses because it does not need to provide collateral to access funding [21-23]. In addition, P2P lending has the advantage of providing loans with lower interest rates and without collateral to borrowers, while lenders get high returns on investment [23-25].

Although the existence of FinTech can be beneficial for small business owners, not all small business owners are willing to use FinTech financing [26]. The reasons for this are still controversial, such as insufficient knowledge about FinTech, miss perception and feeling insecure or having no confidence to use FinTech [6]. Overall, the barriers for small business owners to adopt FinTech are almost the same as those of other innovation adoptions, namely their resistance to change, so they are reluctant to adopt new technologies including financial innovation such as FinTech [27,28]. In short, although FinTech has the potential to improve financial access for small entrepreneurs, there is not much knowledge about the FinTech adoption process by small business owners, especially in P2P lending [28]. Therefore, the research question is: what factors influence the adoption of FinTech in small businesses?

The Unified Theory of Acceptance and Use of Technology (UTAUT2) is a popular contemporary adoption theory that is useful for analyzing the determinants of intention to use new technology [29]. Although it is useful to explain the technology adoption model at the individual level, UTAUT 2 has many deficiencies in explaining the technology adoption factors at the enterprise level [30,31]. As mentioned by many previous studies [32,33], SMEs have limitations in adopting new innovations due to a lack of human capital, insufficient knowledge and the mindset of owners who resist change. Therefore, the modified UTAUT2 should recognize such variables to improve the explanatory power of the model. Our second research question is: can modified UTAUT 2 increase the predictive power of small business adoption of FinTech?

This study identifies and analyzes the determinants of small business owners to adopt FinTech P2P lending by applying the updated UTAUT2 model. In addition, because the purpose of FinTech adoption is to increase financial and business capacity, this study also identifies the role of FinTech adoption on the sustainability of small businesses. The third research question in this study is: can FinTech adoption affect the sustainability of small businesses? As mentioned by Pizzi et al. [20], that the limitations of the existing literature are not sufficient to prove the relationship between FinTech and sustainable business, especially for small business actors, what is new in this study is finding the impact of FinTech P2P lending on the sustainability of small food business. Overall, this study will propose a comprehensive model of FinTech P2P lending adoption by small food business owners. 


\section{Literature Review}

\subsection{FinTech and P2P Lending}

The industrial revolution 4.0 has had an impact on many sectors in business. Financial service is one of the sectors that support the progress of industry 4.0 , namely the emergence of FinTech [20]. FinTech is developing rapidly in a variety of different contexts, delivering new innovations in products and services using contemporary technology [34,35]. FinTech consists of applications that have large-scale machines that use the internet of things (IoT) for financial convenience [36]. Meanwhile, Haddad and Hornuf [37] define FinTech as a financial facility that uses digital technology in providing its products and services. The existence of FinTech can reduce the financing gap for small enterprises by introducing new business models based on information technology, as well as improving services from existing financial institutions [25,37]. In addition, the emergence of FinTech has led to the disintermediation of financial services, and the need for risk protection for consumers and investors [36,38].

$\mathrm{P} 2 \mathrm{P}$ lending is one of the FinTech services that is currently growing rapidly $[39,40]$. $\mathrm{P} 2 \mathrm{P}$ lending is often referred to as marketplace lending or crowd lending, which is one of the main forms of crowd funding [41,42]. Due to the rapid advancement of information technology and the difficulty of small businesses in receiving credit from banks, P2P lending platforms received a positive response in the SMEs' financing market $[39,42]$. P2P lending itself includes financing sourced from crowd funding and financial institutions, which can be channeled to small businesses or consumers. So, P2P lending can be said to be a financing model, namely a multi-sided platform that can facilitate financial institutions and small investors to fund startups and small businesses. P2P platforms have brought together individual investors with small business firms, and usually offer credit on a variety of systems other than the interest system $[43,44]$.

\subsection{Factor Affecting FinTech Adoption by Small Business}

When someone is offered a technological innovation product and learns to use that technology, it has an impact on their performance. Then they will adopt the new technology in the future, with the hope that its performance will increase [31]. Najib and Fahma [6] also found that performance expectations were a key factor influencing small food processing businesses to adopt digital payment systems. In terms of FinTech adoption, expectations of better performance from small businesses will also affect FinTech adoption. Therefore, the hypothesis proposed in this study is:

Hypothesis 1 (H1). Performance expectations have a positive effect on FinTech adoption.

Consumers can accept new technology if it is perceived as user-friendly and easy to use, so that they can easily adopt it quickly. Najib and Fahma [6] also found that among small business owners, the ease in using digital payment systems makes it easier for them to adopt. Several previous studies $[31,45,46]$ have shown that when consumers choose to compare the latest technology options with the latest technology and find that the latest technology has advantages in its use, their interest in adopting the technology increases. Previous research has also shown that perceived use directly affects adoption rates [31,47]. Referring to the empirical findings, the research hypothesis is:

Hypothesis 2 (H2). Effort expectancy positively influences FinTech adoption.

Social influence is a person's response to receiving approval to do certain things by the immediate environment [31]. The influence of social factors actually comes from the behavioral attitude theories developed by Fishbein and Ajzen [48]. Given the importance of this variable in influencing the adoption process, it is included as a predictor in the UTAUT model and re-validated in the UTAUT2 model [31]. In addition, research related to the use of FinTech in the context of private banking customers in India found that social 
influence has a positive effect on FinTech adoption [49]. In the context of Indonesia, the adoption of new technology by consumers was affected by social factors [6]. We argue that this also applies to the adoption behavior of small business owners in Indonesia in the context of FinTech adoption. Therefore, the hypothesis proposed in the study is:

Hypothesis 3 (H3). Social factors have a positive effect on FinTech adoption.

Facilitation conditions are part of consumer perceptions in the form of support and available resources to carry out an activity [46,50]. Facilitating conditions also explain the extent to which users or consumers believe that providers, with the support of their own technical and organizational infrastructure, can assist in the use of new technologies, products and services [51,52]. In the context of developing countries, the availability of adequate facilitation conditions has an influence on the new technology adoption. Research by Khan et al. [53] in Pakistan provides empirical evidence that facilitation conditions have a positive effect on online banking adoption. In the case of P2P lending through FinTech, we argue that consumers in Indonesia still consider the condition of facilitation as a determinant variable in its adoption. The hypotheses proposed in this study are:

Hypothesis 4 (H4). Facilitation conditions have a positive effect on FinTech adoption.

Hedonic motivation is the preferred desire in the use of technology, and this has proven to be a determining factor in the process of recognizing and adopting new technology $[47,54]$. Research by Zeba et al. [55] proved that hedonic motivation was able to adopt consumers towards the online purchasing process in the case of the airline industry. In addition, hedonic motivation is also an intrinsic factor that makes technology users like FinTech cognitively attached to a platform [51]. The hypotheses proposed in this study are:

Hypothesis 5 (H5). Hedonic motivation positively influences FinTech adoption.

The value of price is related to the cognitive characteristics of consumers, where consumers always calculate rationally between the costs incurred and the benefits they feel [51]. In the adoption process of P2P lending channeled through FinTech, consumers will calculate and consider the cost of funds that arise [21], as this will have a direct impact on their company's finances. Empirical research conducted by Khan et al. [53], noted that in the context of online banking adoption in Pakistan as a developing country, the price value has a positive effect on adoption. We argue that in the Indonesian context, FinTech adoption is also influenced by price value. Therefore, the hypothesis proposed in this study is:

Hypothesis 6 (H6). The price value positively influences FinTech adoption.

In the UTAUT2 model, Venkatesh et al. [31] explained that habits reflect how consumers tend to act in a structured manner, which results from repeated learning; this means that behavior is influenced by repetitive activities that become habits. Previous research has shown that habit influences adoption behavior [55]. Moreover, research conducted by Chang et al. [54] mentioned that a consumer's habit has an impact on use behavior significantly. Hence, the hypothesis of this study is as follows:

Hypothesis 7 (H7). Habit behavior has positive impact on FinTech adoption.

The knowledge variable is closely related to one's technology adoption behavior, as the process of adopting new technology generally requires special knowledge and skills [56]. In order to adopt P2P lending through FinTech, knowledge and ability to use a computer or smartphone connected to the internet is required [57]. Good knowledge of FinTech and 
P2P lending will make it easier for consumers to adopt FinTech P2P lending as a source of financing $[57,58]$. Hence, the hypothesis of this study is as follows:

Hypothesis 8 (H8). Knowledge has positive impact on FinTech adoption.

In the context of business related to finance, security perceptions reflect consumers' perceptions of the uncertainty that the system can carry out transactions safely $[59,60]$. FinTech is a relatively new thing in Indonesia, especially for small entrepreneurs [6]. Concerns about the use of FinTech arise due to news about financial crimes committed through FinTech - this increases the perceived risk involved in using FinTech. Perceived risk has a negative impact on technology adoption [61,62], so that many consumers fall into the late adopter category in terms of adopting new technology as they perceive this risk $[63,64]$. Conversely, perceptions about the security of the transaction system through the FinTech platform will have a positive influence on adoption [65]. Based on the existing literature, the hypothesis proposed in this study is:

Hypothesis 9 (H9). Perceived security has a positive influence on FinTech adoption.

\subsection{FinTech Adoption and Business Sustainability}

In competitive situations, small businesses often find it difficult to survive [66]. This is partly due to the weakness of small businesses in terms of innovation, and a lack of capacity in developing their organizations [32]. Several previous studies noted that the factor of limited capital is the main inhibiting factor for small businesses to innovate and increase their capacity, which thus has a negative impact on the continuity of their business $[13,34]$. The existence of FinTech provides a friendlier alternative financing model for small business actors [67]. Therefore, the adoption of FinTech by small businesses should be able to increase the organizational capacity, enabling them to compete and survive in competition so that their business can be sustainable. Therefore, in this study we propose the following hypothesis:

Hypothesis 10 (H10). FinTech adoption influences business sustainability.

Based on the literature and the development of hypotheses as previously described, an initial model of the factors that influence FinTech adoption and their influence on business sustainability is compiled (see Figure 1).

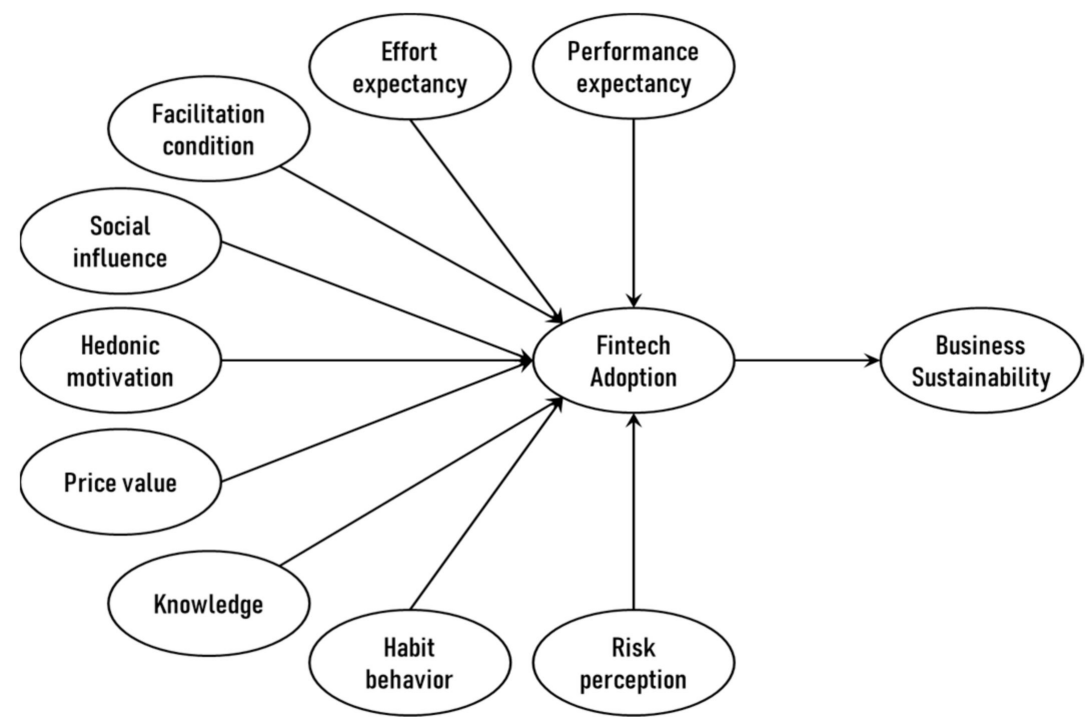

Figure 1. Initial model for FinTech adoption by small business. 


\section{Methods}

The purpose of this study is to identify and analyze the determinants of small business owners to adopt FinTech P2P lending by applying the updated UTAUT2 model. In addition, because the purpose of FinTech adoption is to increase financial and business capacity, this study also wants to identify the role of FinTech adoption in the sustainability of small businesses. We formulated the following research questions: (1) what factors affect FinTech adoption in small business?; (2) can modified UTAUT 2 improve the predictive power of FinTech adoption by small business?; and (3) does FinTech adoption affect small business sustainability? To answer these questions, we adopted a survey method. As mentioned by Chin and Newsted [68], the survey method is suitable for estimating behavior and relationships between variables. In addition, according to Huang and Benyoucef [69], there have been many studies using survey methods to measure behavior changes in social and e-commerce studies.

\subsection{Survey Instrument}

The measurement tools in this research were adopted from Venkatesh et al. [31], with several developments. From the UTAUT2 model we adopted eight latent variables: effort expectancy; facilitating condition; social influence; price value; habit behavior; performance expectancy; and hedonic motivation FinTech adoption. Several new latent variables have been added, namely knowledge, perceived security and business sustainability, so that the total indicator variables in the questionnaires is 35 . A five-point Likert scale (strongly disagree $=1$, strongly agree $=5$ ) was applied for all items. To ensure the validity of the contents of the measurement scale, we conducted an extensive literature review and consulted several experts in the field. The consultation in the formulation of the questionnaire involved five experts, namely two FinTech experts, two small business experts and one consumer behavior expert.

\subsection{Data Collection}

Sampling was done by using purposive technique with the criteria: 1 . Owner of a small food business; 2. Having had interaction with FinTech; and 3. Located in Jakarta and surrounding area. Questionnaires are distributed to owners of small businesses through online surveys with the help of Google Form. In the context of FinTech adoption research, using online surveys to collect the data is relevant. Moreover, due to their ease of formation and wide reach, online surveys are more advantageous [70].

Regarding the number of samples, this study follows the rule of thumb of the SEM tool, where the sample size is $5-10$ times the number of indicators. [71,72]. Since the number of indicators in this study was 35 , the minimum sample must be 175 . We distributed questionnaires to 200 participants. Then, the incoming questionnaire was checked again, cleaned, and incomplete questionnaire entries were not included in data processing. There are 184 samples that can be processed further after the cleaning process.

\subsection{Data Analysis}

The Structural Equation Modeling (SEM) was applied in research for testing between latent variables. SEM is a data analysis technique that can test a series of relatively complex relationships that are built simultaneously between the independent and the dependent variable, where each variable can be built from several indicators [72]. SEM aims to estimate the relationship between variables contained in a model, both between indicators in a variable, and the relationship between latent variables [71]. SEM is an approach that integrates two analyses, namely factor analysis and regression analysis. For two-stage SEM analysis, we first test the measurement model in the form of construct validity and reliability of each indicator; and second, test the structural model to determine whether there is influence between variables or correlation between constructs [73]. 


\section{Research Findings}

\subsection{Respondent Profile}

The dominant male gender were respondents in the study (68.5\%). This is in accordance with the characteristics of small businesses in Indonesia, where the majority of entrepreneurs are dominated by men [6]. Furthermore, small food businesses are dominated by entrepreneurs who are less than 40 years old $(66.9 \%)$, with the highest education levels being senior high school (42.9\%) and junior high school (33.7\%). $87 \%$ of respondents have been in business for fewer than five years.

In terms of business size, the majority of respondents (53.3\%) in this study (see Table 1 ) had a sales value of less than 25 million rupiah per month, or less than 300 million rupiah per year. Overall, the respondents in this study met the micro and small business category, based on Indonesian regulations. The majority of respondents in this study $(60.9 \%)$ had received financing from P2P lending through FinTech. Meanwhile, the three main reasons they proposed financing from FinTech were for the purchase of raw materials $(89.1 \%)$, for operational costs $(77.7 \%)$ and for increased production capacity $(71.7 \%)$.

Table 1. Characteristic of respondent.

\begin{tabular}{|c|c|c|c|}
\hline Characteristic & Criteria & $\begin{array}{l}\text { Frequency } \\
(n=184)\end{array}$ & Percentage (\%) \\
\hline \multirow{2}{*}{ Gender } & Male & 126 & 68.5 \\
\hline & Female & 58 & 31.5 \\
\hline \multirow{4}{*}{ Age } & $<30$ & 54 & 29.4 \\
\hline & $30-40$ & 69 & 37.5 \\
\hline & $41-50$ & 42 & 22.8 \\
\hline & $>50$ & 19 & 10.3 \\
\hline \multirow{3}{*}{ Education } & Junior high school & 62 & 33.7 \\
\hline & Senior high school & 79 & 42.9 \\
\hline & Bachelor & 43 & 23.4 \\
\hline \multirow{3}{*}{ Length of business } & $<2$ years & 82 & 44.6 \\
\hline & $2-5$ years & 78 & 42.4 \\
\hline & $>5$ years & 24 & 13.0 \\
\hline \multirow{3}{*}{ Sales value } & $<25$ million IDR/month & 98 & 53.3 \\
\hline & 25-50 million IDR/month & 56 & 30.4 \\
\hline & $>50$ million IDR/month & 30 & 16.3 \\
\hline \multirow{3}{*}{$\begin{array}{l}\text { Experience using } \\
\text { FinTech P2P lending }\end{array}$} & One times & 112 & 60.9 \\
\hline & 2 times & 49 & 26.6 \\
\hline & $>2$ times & 23 & 12.5 \\
\hline $\begin{array}{l}\text { Reason to use FinTech } \\
\text { P2P Lending }{ }^{(*)}\end{array}$ & $\begin{array}{ll}- & \text { to increase } \\
- & \text { production capacity } \\
- & \text { to purchase equipment } \\
- & \text { to purchase raw material } \\
- & \text { to increase operational cost } \\
- & \text { to increase marketing cost }\end{array}$ & $\begin{array}{l}132 \\
67 \\
164 \\
143 \\
55 \\
49\end{array}$ & $\begin{array}{l}71.7 \\
36.4 \\
89.1 \\
77.7 \\
29.9 \\
26.6\end{array}$ \\
\hline
\end{tabular}

(*) Respondent may answer more than one option.

\subsection{Measurement Model}

The research instruments were tested for the reliability of the AMOS application in the form of composite reliability and Cronbach's alpha, while the instrument validity was 
tested with convergent validity and discriminant validity. For all items, the loading factor has a value greater than 0.70 , which means a good indicator. The Cronbach alpha value of composite reliability for all scales is greater than the smallest threshold of 0.70 , which means that all scales are reliable (see Table 2). The square root value of the extract of mean variation (AVE) of convergent validity was obtained at a number higher than the cut-off level (0.70), which means that all scales are reliable (see Table 2). The discriminant validity by Fornell and Larcker's test shows that the extracted variance is relatively high for each factor, compared to the inter-scale correlation, indicating that the nine constructs are valid (see Table 3).

Table 2. Loading factor.

\begin{tabular}{|c|c|c|c|c|}
\hline Variables & Loading Factor & AVE & $\begin{array}{l}\text { Comp. } \\
\text { Reliability }\end{array}$ & Cronbach's $\alpha$ \\
\hline Performance expectancy & & 0.757 & 0.798 & 0.911 \\
\hline - $\quad$ Service process of FinTech is faster & 0.840 & & & \\
\hline $\begin{array}{l}\text { - FinTech service make it easy to connect } \\
\text { with investor }\end{array}$ & 0.853 & & & \\
\hline $\begin{array}{l}\text { - FinTech platform make it easy to } \\
\text { connect with lender }\end{array}$ & 0.863 & & & \\
\hline $\begin{array}{l}\text { - FinTech platform make it easy to } \\
\text { monitor transaction }\end{array}$ & 0.862 & & & \\
\hline Effort expectancy (EE) & & 0.823 & 0.776 & 0.907 \\
\hline $\begin{array}{l}\text { - Learning how to use a FinTech platform } \\
\text { is easy for me }\end{array}$ & 0.851 & & & \\
\hline $\begin{array}{l}\text { - Financing procedures is clear and } \\
\text { understandable }\end{array}$ & 0.842 & & & \\
\hline $\begin{array}{l}\text { - I find it easy to propose financing in } \\
\text { FinTech company }\end{array}$ & 0.861 & & & \\
\hline - $\quad$ FinTech platform is easy to be used & 0.835 & & & \\
\hline Social influence (SI) & & 0.811 & 0.823 & 0.921 \\
\hline $\begin{array}{l}\text { - People who are important to me think I } \\
\text { must use FinTech }\end{array}$ & 0.813 & & & \\
\hline $\begin{array}{l}\text { - People who influence my behavior think } \\
\text { I should use FinTech }\end{array}$ & 0.821 & & & \\
\hline $\begin{array}{l}\text { - People whose opinions that I value } \\
\text { prefer I use FinTech }\end{array}$ & 0.811 & & & \\
\hline Facilitation condition (FC) & & 0.740 & 0.725 & 0.843 \\
\hline $\begin{array}{l}\text { - I have the resources necessary to use a } \\
\text { FinTech platform }\end{array}$ & 0.772 & & & \\
\hline $\begin{array}{l}\text { - FinTech system is compatible with our } \\
\text { business model }\end{array}$ & 0.761 & & & \\
\hline $\begin{array}{l}\text { - I can get help from others when I have } \\
\text { difficulties }\end{array}$ & 0.733 & & & \\
\hline Hedonic motivation (HM) & & 0.797 & 0.732 & 0.876 \\
\hline - Using FinTech platform is fun & 0.782 & & & \\
\hline - Using FinTech platform is enjoyable & 0.784 & & & \\
\hline
\end{tabular}


Table 2. Cont.

\begin{tabular}{|c|c|c|c|c|}
\hline Variables & Loading Factor & AVE & $\begin{array}{l}\text { Comp. } \\
\text { Reliability }\end{array}$ & Cronbach's $\alpha$ \\
\hline - Using FinTech platform is pleasant & 0.773 & & & \\
\hline Price value (PV) & & 0.814 & 0.777 & 0.887 \\
\hline $\begin{array}{l}\text { - I feel the benefit is higher than cost } \\
\text { when I use FinTech }\end{array}$ & 0.911 & & & \\
\hline - I think the interest rate/fee is lower & 0.894 & & & \\
\hline $\begin{array}{l}\text { - I think the cost of fund of FinTech P2P } \\
\text { lending is lower }\end{array}$ & 0.899 & & & \\
\hline Habit behavior $(\mathrm{HB})$ & & 0.799 & 0.758 & 0.869 \\
\hline $\begin{array}{l}\text { Using smart phones to access FinTech } \\
\text { has become a habit }\end{array}$ & 0.888 & & & \\
\hline $\begin{array}{l}\text { - Using smart phones for payment has } \\
\text { become natural to me }\end{array}$ & 0.867 & & & \\
\hline $\begin{array}{l}\text { I must use smart phones for accessing } \\
\text { financial service }\end{array}$ & 0.873 & & & \\
\hline Knowledge (K) & & 0.841 & 0.841 & 0.917 \\
\hline $\begin{array}{l}\text { - I know product of FinTech P2P } \\
\text { lending well }\end{array}$ & 0.921 & & & \\
\hline $\begin{array}{l}\text { I know the procedures to access a } \\
\text { FinTech platform }\end{array}$ & 0.914 & & & \\
\hline $\begin{array}{l}\text { - I know requirement to get financing } \\
\text { from FinTech }\end{array}$ & 0.917 & & & \\
\hline Perceive security (PS) & & 0.804 & 0.792 & 0.914 \\
\hline - $\quad$ FinTech systems are secure systems & 0.877 & & & \\
\hline $\begin{array}{l}\text { - I feel secure providing information } \\
\text { when using FinTech }\end{array}$ & 0.887 & & & \\
\hline $\begin{array}{l}\text { I am not worried that information I } \\
\text { provide when using a FinTech platform } \\
\text { could be used by other people }\end{array}$ & 0.884 & & & \\
\hline FinTech adoption (FA) & & 0.867 & 0.831 & 0.941 \\
\hline $\begin{array}{l}\text { I have downloaded a FinTech platform } \\
\text { for P2P lending }\end{array}$ & 0.912 & & & \\
\hline $\begin{array}{l}\text { - I have proposed financing from a } \\
\text { FinTech company }\end{array}$ & 0.899 & & & \\
\hline $\begin{array}{l}\text { - I used financing from a } \\
\text { FinTech company }\end{array}$ & 0.903 & & & \\
\hline Business sustainability (BS) & & 0.832 & 0.825 & 0.937 \\
\hline $\begin{array}{l}\text { - Financing from FinTech increases } \\
\text { business capability }\end{array}$ & 0.892 & & & \\
\hline $\begin{array}{l}\text { - By financing from FinTech, our business } \\
\text { increases sustainably }\end{array}$ & 0.876 & & & \\
\hline $\begin{array}{l}\text { - Financing from FinTech improves } \\
\text { business competitiveness }\end{array}$ & 0.889 & & & \\
\hline
\end{tabular}


Table 3. Discriminant validity.

\begin{tabular}{|c|c|c|c|c|c|c|c|c|c|c|c|c|c|}
\hline Variables & Mean & SD & PE & $\mathrm{EE}$ & SI & FC & HM & PV & HB & $\mathbf{K}$ & PS & FA & BS \\
\hline PE & 4.525 & 1.341 & 0.934 & & & & & & & & & & \\
\hline $\mathrm{EE}$ & 4.432 & 1.524 & 0.635 & 0.921 & & & & & & & & & \\
\hline SI & 4.751 & 1.276 & 0.588 & 0.526 & 0.873 & & & & & & & & \\
\hline $\mathrm{FC}$ & 4.612 & 1.365 & 0.623 & 0.611 & 0.638 & 0.824 & & & & & & & \\
\hline $\mathrm{HM}$ & 4.211 & 1.352 & 0.737 & 0.475 & 0.536 & 0.604 & 0.833 & & & & & & \\
\hline PV & 4.525 & 1.341 & 0.635 & 0.526 & 0.526 & 0.635 & 0.635 & 0.853 & & & & & \\
\hline HB & 4.432 & 1.524 & 0.588 & 0.611 & 0.611 & 0.588 & 0.588 & 0.588 & 0.822 & & & & \\
\hline K & 4.751 & 1.276 & 0.623 & 0.475 & 0.475 & 0.623 & 0.623 & 0.623 & 0.623 & 0.911 & & & \\
\hline PS & 4.612 & 1.365 & 0.737 & 0.526 & 0.526 & 0.737 & 0.737 & 0.737 & 0.737 & 0.737 & 0.916 & & \\
\hline FA & 4.211 & 1.352 & 0.588 & 0.611 & 0.611 & 0.588 & 0.588 & 0.588 & 0.588 & 0.588 & 0.588 & 0.831 & \\
\hline BS & 4.612 & 1.276 & 0.623 & 0.475 & 0.475 & 0.623 & 0.623 & 0.623 & 0.623 & 0.623 & 0.623 & 0.623 & 0.899 \\
\hline
\end{tabular}

Note: $n=184$, squared roots of extract of mean variation (AVE) extracted are shown in italics on the diagonal, and variable correlations are below the diagonal. Performance expectancy (PE), Effort expectancy (EE), Social influence (SI), Facilitating condition (FC), Hedonic motivation (HM), Price value (PV), Habit behavior (HB), Knowledge (K), Perceive security (PS), FinTech adoption (FA) and Business sustainability (BS).

\subsection{Structural Model}

The results of the study found the following fit indexes: CMIN/DF $=1.428, \mathrm{CFI}=0.942$; $\mathrm{TLI}=0.925$; RMSEA $=0.064$. Such indexes were above the minimum recommended cut-off value, thus indicating an appropriate model fit [73]. The detail of goodness of fit can be seen in Table 4.

Table 4. Goodness of fit.

\begin{tabular}{cccc}
\hline Indicators & Value & Standard & Category \\
\hline RMSEA & 0.064 & $0.05 \leq$ RMSEA $\leq 0.08$ & Good Fit \\
\hline CMIN/DF & 1.428 & $\leq 2.00$ & Good Fit \\
\hline NFI & 0.915 & NFI $\geq 0.9$ & Good Fit \\
\hline IFI & 0.931 & IFI $\geq 0.9$ & Good Fit \\
\hline TLI & 0.925 & TLI $\geq 0.9$ & Good Fit \\
\hline CFI & 0.942 & CFI $\geq 0.9$ & Good Fit
\end{tabular}

The structural model is evaluated to test ten research hypotheses. Table 5 shows the test results. This study found that performance expectations $(\beta=0.513, p$-value $=0.006)$, social influence $(\beta=0.611, p$-value $=0.000)$, facilitating conditions $(\beta=0.201, p$-value $=0.018)$, price value $(\beta=0.634, p=0.001)$ and knowledge $(\beta=0.535, p$-value $=0.000)$ have positive impacts on FinTech adoption. Therefore, hypotheses 1, 3, 4, 6, 8 and 9 are accepted. Meanwhile, variables of effort expectancy $(\beta=0.012$, $p$-value $=0.071)$, hedonic motivation $(\beta=0.034, p$-value $=0.110)$ and habit behavior $(\beta=0.020, p$-value $=0.110)$ have no significant effect on FinTech adoption. Therefore, hypotheses 2, 5 and 7 are rejected. Furthermore, this study found that FinTech adoption $(\beta=0.476, p$-value $=0.004)$ influences the business sustainability of small business, meaning hypothesis 10 is accepted. 
Table 5. Hypothesis testing.

\begin{tabular}{lccc}
\hline \multicolumn{1}{c}{ Hypotheses } & $\beta$ & $p$-Values & Decision \\
\hline H1: Performance expectancy $\rightarrow$ FinTech adoption & 0.513 & $0.006^{* * *}$ & Supported \\
\hline H2: Effort expectancy $\rightarrow$ FinTech adoption & 0.012 & 0.071 & Not Supported \\
\hline H3: Social influence $\rightarrow$ FinTech adoption & 0.611 & $0.000^{* * *}$ & Supported \\
\hline H4: Facilitation condition $\rightarrow$ FinTech adoption & 0.201 & $0.018^{* *}$ & Supported \\
\hline H5: Hedonic motivation $\rightarrow$ FinTech adoption & 0.034 & 0.090 & Not Supported \\
\hline H6: Price value $\rightarrow$ FinTech adoption & 0.634 & $0.001^{* * *}$ & Supported \\
\hline H7: Habit behavior $\rightarrow$ FinTech adoption & 0.020 & 0.110 & Not Supported \\
\hline H8: Knowledge $\rightarrow$ FinTech adoption & 0.535 & $0.000^{* * *}$ & Supported \\
\hline H9: Perceive security $\rightarrow$ FinTech adoption & 0.492 & $0.000^{* * *}$ & Supported \\
\hline H10: FinTech adoption $\rightarrow$ Business sustainability & 0.476 & $0.004^{* * *}$ & Supported \\
\hline
\end{tabular}

${ }^{* *} p<0.05 .{ }^{* * *} p<0.01 . R^{2}$ for business sustainability: $0.45, R^{2}$ for FinTech adoption 0.64 .

\subsection{Coefficient Determination $\left(R^{2}\right)$}

The $R^{2}$ shows the ability of the research model to explain the contribution of the determinants to explain changes that occur in FinTech adoption, and can also assess how well the model is expected to explain and predict future outcomes. Thus, a high $\mathrm{R}^{2}$ value can produce correct predictions [68]. The test results in the research model explain a substantial variant of FinTech adoption $\left(R^{2}=0.64\right)$, which means that the variables of performance expectancy, effort expectancy, social influence, facilitation conditions, hedonic motivation, price values and habits explain $64 \%$ of the variation in changes in the adoption of FinTech. In addition, the model explains the moderate variations in business sustainability change $\left(R^{2}=0.45\right)$, which indicates that the FinTech adoption variable accounts for $45 \%$ of variation in business sustainability.

\section{Discussion: FinTech, Small Food Business and Open Innovation}

\subsection{FinTech and Small Food Business}

Research on the behavior of adopting new technologies using the UTAUT2 approach has been widely discussed by researchers $[47,51,53]$. However, research on the adoption of FinTech as a channel in P2P lending has not been widely carried out, especially in developing countries such as Indonesia. The adoption of FinTech is different from the adoption of other technologies such as the adoption of computers, smartphones or others. FinTech adoption in the context of P2P lending is the adoption of a financing system using digital technology and the internet as a channel [23,34,37], in which not all small business owners are familiar with this type of financing. Therefore, analysis of FinTech adoption by small food businesses owners requires a different approach, which is not sufficient if it is only explained by the UTAUT2 model.

In this study, the business context, namely financial business, and the environmental context, namely developing countries, are strong reasons for adding variables of perceived security and knowledge to the model. Moreover, because FinTech for small businesses is a more accessible alternative to financing [14], FinTech adoption should increase the sustainability of small businesses [20,34]. With FinTech, the capacity of small businesses increases and allows them to be more competitive and survive in the market. Therefore, explaining the relationship between FinTech adoption and small business sustainability is an important novelty in this study.

In the context of small food enterprises in Indonesia, not all exogenous variables in the original UTAUT2 model can be significant predictors of influencing FinTech adoption. The empirical findings show that the variable performance expectations, social influence, facility conditions and price value influence FinTech adoption. This is in line with several studies on technology adoption in different contexts [31]. The variables in the original 
UTAUT2 model which in this study did not affect adoption were business expectations, hedonic motivation and habitual behavior. This finding differs from previous studies by Palau-Saumell et al. [48], which stated that business expectations and hedonic motivation have a positive effect on adoption in the context of online purchases. However, these results support the findings of several previous researchers [52,66], who stated that the business expectancy variable has no effect on adoption.

This study proposes a modified UTAUT2 model by adding knowledge and perceived security variables. The results showed that these two variables had a significant effect on FinTech adoption by small food business owners in Indonesia. The variable of knowledge in the context of FinTech adoption in Indonesia is a strong predictor $(\beta=0.535)$. Good knowledge of FinTech as a new technology and P2P lending as an alternative financing system that are suitable for small businesses have a big impact on adoption. This is in accordance with several previous studies [56,57], which found that a complete knowledge about how a new technology product works will influence someone to try and use the product.

The perceived safety variable was also added as a predictor of adoption that enhanced the original UTAUT2 model in this study. The results showed that the perception of security had a significant effect on adoption. This result is in line with the findings of Morosan and DeFranco [66], which stated the importance of perceptions of security in implementing online payments. In an Indonesian context, financial transactions through digital systems are perceived by consumers as something risky [6], and therefore security becomes the significant predictor that influences FinTech adoption. The security expected by users in this case is security in the transaction process and security in safeguarding certain personal information. Data confidentiality is an important factor that consumers consider when applying for financing from FinTech.

The modification of the original UTAUT2 model with the addition of knowledge and perceived security variables was proven to strengthen the predictive power of the new technology adoption model. This can be seen from the high $R^{2}$ value of 0.64 , which means that the predictive power of the model is $64 \%$, or is in the strong category. When compared with the original model, which is generally below 0.3 for the predictive power of the adoption variable [52], this research has contributed to refining the UTAUT2 model in the context of FinTech adoption by small business owners in developing countries.

The next important thing that resulted from this study is that this study succeeded in proving a positive relationship between P2P lending adoption through FinTech and the sustainability of small food businesses. To date, business sustainability has been an important issue for small businesses-especially small businesses that are still in the startup stage [34]. Lack of capital is a critical problem besides market and competition problems [33]. This research provides an empirical solution to the problem of small business sustainability by increasing its operational capacity through funding from FinTech P2P lending.

The empirical findings prove that the variables of social influence and price value are the strongest determinants of FinTech adoption by small food business owners in Indonesia. The strength of social influence variable in this study is closely related to the context of Indonesian society, where socially and culturally, Indonesian people have a fairly high power distance [65]. In this case, the role of opinion leaders and patrons greatly affects consumers' decision-making behavior. Therefore, FinTech P2P lending managers need to socialize and approach influential people or opinion leaders in society, and make them supporters to convince small business owners about the benefit of FinTech P2P lending. In addition, positive news about FinTech needs to be disseminated massively. Positive news is part of the social influence that can influence small business managers in adopting FinTech.

FinTech managers need to use social media and increase the involvement of competent and influential figures in public conversations on social media about FinTech. This will have a strong social influence on small business actors in adopting FinTech, as they will feel that many other entrepreneurs in their environment have already benefited a lot from FinTech adoption. Socialization of FinTech P2P lending through social media can also 
increase the knowledge of small business owners on what FinTech is and how it works. The results of this study found that the knowledge variables also have a strong influence on adoption. Therefore, complete information is needed about FinTech itself, as well as the types of financing available and the procedures for obtaining financing from FinTech P2P lending through social media and other socialization tools.

Regarding price value, small food business owners are quite rational in choosing financing. They do not choose financing only because of the ease of applying for financing, but also think about how to get the best price from all available financing offers. Therefore, FinTech managers need to establish a competitive pricing strategy to be able to penetrate the small food businesses segment. In this case, interest subsidies from the government, such as those channeled through banks, can also be channeled through FinTech, so that small food businesses can enjoy even better prices.

Low financing costs will greatly help small businesses in maintaining their business sustainability, as their income does not run out to pay debts, but can be used to increase the business and operational capacity of the company. This will improve the performance of small food businesses, which in turn can increase the ability of small businesses to survive, and even grow and develop properly. The consequence of the increase in price value for small businesses is that FinTech managers are required to be able to operate efficiently and find "angle" investors who want to invest in small businesses without expecting large profit margins. With good technology-based data management, FinTech will be able to achieve efficiency.

\subsection{FinTech in Small Food Business and Its Relation with Open Innovation}

The use of resources from outside the organization in terms of innovation is commonly referred to as open innovation [71]. For small and medium enterprises where they have limited resources to innovate [67], open innovation is a solution that means small and medium enterprises can remain competitive. Previously, open innovation was generally conducted in technology-intensive industry tries such as the information technology or pharmaceutical sectors [72]. The food industry is considered a relatively mature and slowgrowing business, in which the level of investment in R\&D activity is relatively low [73]. Therefore, the food industry is considered to rarely use open innovation in its business.

The trend of consumers towards food products is currently experiencing a shift, where they are increasingly interested in issues of health and food safety. Consumers also demand high-quality food products that are able to meet their satisfaction [74]. In order to meet changing consumer demands, some food companies are innovating with their internal R\&D [75]. However, many companies do not have the capacity to meet the challenges of changing consumer demand with their own resources; they need collaboration with various external parties such as universities, research institutions and the government to develop innovation. In this context, the idea of Open Innovation is also very relevant for the food industry. Particularly for small food businesses, open innovation is very helpful.

The literature clearly shows that although open innovation was initially adopted by companies engaged in the high-tech sector, nowadays it has also been adopted by food companies that have been considered low-tech sectors [75]. The results of this study provide empirical evidence that the food industry, especially small food businesses, have benefited from FinTech adoption. FinTech helps the sustainability of the small food business, where FinTech itself is not only made by the large banking industry, but is an open innovation product from start-up companies that can become competitors for banks [76]. Therefore, from the perspective of open innovation, the food industry can currently be said to have adopted open innovation in its business.

\section{Conclusions}

This study uses a modified version of the updated UTAUT2 model in the case of small businesses to examine the factors affecting the adoption of FinTech P2P lending. Related to the purpose of FinTech adoption to increase financial and business capacity, 
this study also identifies the effect of FinTech adoption on the sustainability of small businesses. The survey was conducted on 184 small food business owners who participated as respondents, and SEM-PLS was used to examine the research model and its appropriate hypotheses. The main determinants are identified and tested empirically against small business actors in using the FinTech P2P Lending application and their implications for business sustainability.

The results of the study found that performance expectations, social influence, facilitation conditions, price value, knowledge and security perceptions influenced the adoption of FinTech by small food business owners. The variable of price value and social influence is the strongest determinant of FinTech adoption by small food business owners in Indonesia. The variables of business expectations, hedonic motivation and habitual behavior do not determine whether small business actors adopt FinTech applications. Another important finding from this study was to prove a positive relationship between P2P lending adoption through FinTech and the sustainability of small food businesses. Business sustainability has been an important issue for small businesses, especially those who are still in the startup stage. Lack of capital is the main problem faced so far, and this study provides an empirical solution to the problem of small business sustainability by increasing their operational capacity through funding from FinTech P2P lending.

This research is part of a preliminary study in developing countries, especially in Indonesia, which empirically tested the adoption of FinTech applications for small businesses and the implications for business sustainability. Although this research can bring up some contributions, there are still limitations, especially because the survey data were collected online from small business owners in limited locations, namely Jakarta and its surroundings, which do not represent Indonesia as a whole, as many small business owners are scattered outside Jakarta. Therefore, the generalizability of the research is limited, especially when it is related to the determinants of FinTech adoption, such as different social and social behaviors. In addition, the limitations of the variables used cannot be considered to represent a determining factor for small business owners to adopt the FinTech P2P Lending application. It is recommended that for further research, besides increasing the number of respondents who can reach more small business owners from many areas, other factors are also added, such as; open innovation; trust; and the role of government regulation in FinTech adoption.

Author Contributions: Conceptualisation, M.N., W.J.E. and E.E.; methodology, M.N. and W.J.E.; software, F.F.; validation, F.F. and D.S.; formal analysis, M.N., D.S. and W.J.E.; investigation, F.F. and W.J.E.; resources, M.N., E.E. and D.S.; data curation, M.N. and E.E.; writing-original draft preparation, M.N., W.J.E. and E.E.; writing-review and editing, M.N., D.S., F.F. and W.J.E.; visualization, M.N.; supervision, M.N., D.S. and E.E.; project administration, F.F.; and funding acquisition, M.N. and W.J.E. All authors have read and agreed to the published version of the manuscript.

Funding: This research received no external funding.

Data Availability Statement: Not applicable.

Conflicts of Interest: For this study, the authors declare no conflict of interest.

\section{References}

1. Mbuyisa, B.; Leonard, A. The Role of ICT use in SMEs towards Poverty Reduction: A Systematic Literature Review. J. Int. Dev. 2017, 29, 159-197. [CrossRef]

2. Nursini, N. Micro, small, and medium enterprises (MSMEs) and poverty reduction: Empirical evidence from Indonesia. Dev. Stud. Res. 2020, 7, 153-166. [CrossRef]

3. Abadli, R.; Kooli, C.; Otmani, A. Entrepreneurial culture and promotion of exporting in Algerian SMEs: Perception, reality and challenges. Int. J. Entrep. Small Bus. 2020, 41, 227-240. [CrossRef]

4. Verma, T.L.; Nema, D.K. Role of micro, small and medium enterprises (MSMES) in achieving sustainable development goals. Int. J. Res. Eng. Appl. Manag. 2019, 4, 575-582. [CrossRef]

5. Verboven, H.; Vanherck, L. Sustainability management of SMEs and the UN Sustainable Development Goals. UmweltWirtschaftsForum 2016, 24, 165-178. [CrossRef] 
6. Najib, M.; Fahma, F. Investigating the adoption of digital payment system through an extended technology acceptance model: An insight from the indonesian small and medium enterprises. Int. J. Adv. Sci. Eng. Inf. Technol. 2020, 10, 1702-1708. [CrossRef]

7. Nuriyah, A.; Endri, E.; Yasid, M. Micro, Small-Financial Financing and its Implications on the Profitability of Sharia Banks. DeReMa J. Manaj. 2018, 13, 175-197. [CrossRef]

8. Nemoto, N.; Huang, B.; Storey, D.J. Optimal Regulation of P2P Lending for Small and Medium-Sized Enterprises; Asian Development Bank Institute: Tokyo, Japan, 2019.

9. Dong, Y.; Men, C. SME Financing in Emerging Markets: Firm Characteristics, Banking Structure and Institutions. Emerg. Mark. Financ. Trade 2014, 50, 120-149. [CrossRef]

10. Ridwan Maksum, I.; Yayuk Sri Rahayu, A.; Kusumawardhani, D. A Social Enterprise Approach to Empowering Micro, Small and Medium Enterprises (SMEs) in Indonesia. J. Open Innov. Technol. Mark. Complex. 2020, 6, 50. [CrossRef]

11. Davis, K.; Maddock, R.; Foo, M. Catching up with Indonesia's FinTech industry. Law Financ. Mark. Rev. 2017, 11, 33-40. [CrossRef]

12. Allied Market Research. Peer to Peer Lending Market Outlook-2027. 2020. Available online: https://www.alliedmarketresearch. com/peer-to-peer-lending-market\#: \{\}:text=The\%20global\%20peer\%20to\%20peer,29.7\%25\%20from\%202020\%20to\%202027 (accessed on 5 January 2021).

13. PwC Indonesia. Indonesia's FinTech Lending: Driving Economic Growth through Financial Inclusion. 2019. Available online: https://www.pwc.com/id/en/FinTech/PwC_FinTechLendingThoughtLeadership_ExecutiveSummary.pdf (accessed on 5 January 2021).

14. Lu, L. Promoting SME finance in the context of the FinTech revolution: A case study of the UK's practice and regulation. Bank. Financ. Law Rev. 2018, 33, 317-343.

15. Everett, C.R. Group membership, relationship banking and loan default risk: The case of online social lending. Bank. Financ. Rev. 2015, 7, 15-46. [CrossRef]

16. Herrero, Á.; San Martín, H.; Garcia-De los Salmones, M.d.M. Explaining the adoption of social networks sites for sharing user-generated content: A revision of the UTAUT2. Comput. Hum. Behav. 2017, 71, 209-217. [CrossRef]

17. Ahmed-Ishmel, G.D.; Onyeiwu, C.; Owopetu, O.A. The Impact of Financial Technology in the Operations (Payments/Collections) of SMEs in Nigeria. Int. J. Innov. Res. Dev. 2018, 7, 61-71. [CrossRef]

18. Effiom, L.; Edet, S.E. Financial innovation and the performance of small and medium scale enterprises in Nigeria. J. Small Bus. Entrep. 2020. [CrossRef]

19. Eniola, A.A.; Entebang, H. SME Firm Performance-Financial Innovation and Challenges. Procedia Soc. Behav. Sci. 2015, 195, 334-342. [CrossRef]

20. Pizzi, S.; Corbo, L.; Caputo, A. FinTech and SMEs sustainable business models: Reflections and considerations for a circular economy. J. Clean. Prod. 2020, 281, 125217. [CrossRef]

21. Havrylchyk, O; Verdier, M. The Financial Intermediation Role of the P2P Lending Platforms. Comp. Econ. Stud. 2018, 60, 115-130. [CrossRef]

22. Käfer, B. Peer-to-Peer Lending-A (Financial Stability) Risk Perspective. Rev. Econ. 2018, 69, 1-25. [CrossRef]

23. Thakor, A.V. FinTech and banking: What do we know? J. Financ. Intermediat. 2019, 41, 1-13. [CrossRef]

24. Lenz, R. Peer-to-peer lending: Opportunities and risks. Eur. J. Risk Regul. 2016, 7, 688-700. [CrossRef]

25. Pokorná, M.; Sponer, M. Social Lending and Its Risks. Procedia Soc. Behav. Sci. 2016, 220, 330-337. [CrossRef]

26. Coffie, C.P.K.; Hongjiang, Z.; Mensah, I.A.; Kiconco, R.; Simon, A.E.O. Determinants of FinTech payment services diffusion by SMEs in Sub-Saharan Africa: Evidence from Ghana. Inf. Technol. Dev. 2020, 1-22. [CrossRef]

27. Hamdan, A.R.; Yahaya, J.H.; Deraman, A.; Jusoh, Y.Y. The success factors and barriers of information technology implementation in small and medium enterprises: An empirical study in Malaysia. Int. J. Bus. Inf. Syst. 2016, 21, 477-494. [CrossRef]

28. Nofie, I. The rise and rise of financial technology: The good, the bad, and the verdict. Cogent Bus. Manag. 2020, 7, 1725309. [CrossRef]

29. Momani, A.M. The Unified Theory of Acceptance and Use of Technology. Int. J. Sociotechnol. Knowl. Dev. 2020, 12, 79-98. [CrossRef]

30. Dwivedi, Y.K.; Rana, N.P.; Jeyaraj, A.; Clement, M.; Williams, M.D. Reexamining the Unified Theory of Acceptance and Use of Technology (UTAUT): Towards a Revised Theoretical Model. Inf. Syst. Front. 2019, 21, 719-734. [CrossRef]

31. Venkatesh, V.; Morris, M.G.; Davis, G.B.; Davis, F.D. User acceptance of information technology: Toward a unified view. MIS Q. 2003, 27, 425-478. [CrossRef]

32. Aboelmaged, M.; Hashem, G. Absorptive capacity and green innovation adoption in SMEs: The mediating effects of sustainable organisational capabilities. J. Clean. Prod. 2019. [CrossRef]

33. Najib, M.; Septiani, S.; Nurlaela, S. The role of innovation, entrepreneurial self-efficacy and local uniqueness on marketing performance in small and medium-sized restaurants. J. Foodserv. Bus. Res. 2020, 23, 499-519. [CrossRef]

34. Arner, D.W.; Buckley, R.P.; Zetzsche, D.A.; Veidt, R. Sustainability, FinTech and Financial Inclusion. Eur. Bus. Organ. Law Rev. 2020, 21, 7-35. [CrossRef]

35. Zveryakov, M.; Kovalenko, V.; Sheludko, S.; Sharah, E. FinTech sector and banking business: Competition or symbiosis? Econ. Ann. XXI 2019, 175, 53-57. [CrossRef]

36. Huynh, T.L.D.; Hille, E.; Nasir, M.A. Diversification in the age of the 4th industrial revolution: The role of artificial intelligence, green bonds and cryptocurrencies. Technol. Forecast. Soc. Chang. 2020, 159, 120188. [CrossRef]

37. Haddad, C.; Hornuf, L. The emergence of the global FinTech market: Economic and technological determinants. Small Bus. Econ. 2019, 53, 81-105. [CrossRef] 
38. Lashitew, A.A.; van Tulder, R.; Liasse, Y. Mobile phones for financial inclusion: What explains the diffusion of mobile money innovations? Res. Policy 2019, 48, 1201-1215. [CrossRef]

39. Giudici, P. Financial data science. Stat. Probab. Lett. 2018, 136, 160-164. [CrossRef]

40. Galema, R. Credit rationing in P2P lending to SMEs: Do lender-borrower relationships matter? J. Corp. Financ. 2020, 65, 101742. [CrossRef]

41. Motta, V.; Sharma, A. Lending technologies and access to finance for SMEs in the hospitality industry. Int. J. Hosp. Manag. 2020, 86, 102371. [CrossRef]

42. Coakley, J.; Huang, W. P2P lending and outside entrepreneurial finance. Eur. J. Financ. 2020. [CrossRef]

43. Mc Namara, A.; O'Donohoe, S.; Murro, P. Lending infrastructure and credit rationing of European SMEs. Eur. J. Financ. 2020, 26, 728-745. [CrossRef]

44. Franks, J.; Serrano-Velarde, N.; Sussman, O. Marketplace Lending, Information Aggregation, and Liquidity. Rev. Financ. Stud. 2020, hhaa101. [CrossRef]

45. Valle, B.; Zeng, Y. Marketplace Lending: A New Banking Paradigm? Rev. Financ. Stud. 2019, 32, 1939-1982. [CrossRef]

46. Dwivedi, Y.K.; Shareef, M.A.; Simintiras, A.C.; Lal, B.; Weerakkody, V. A generalised adoption model for services: A cross-country comparison of mobile health (m-health). Gov. Inf. Q. 2016, 33, 174-187. [CrossRef]

47. Khechine, H.; Lakhal, S.; Ndjambou, P. A meta-analysis of the UTAUT model: Eleven years later. Can. J. Adm. Sci. 2016, 33, 138-152. [CrossRef]

48. Fishbein, M.; Ajzen, I. Attitudes towards objects as predictors of single and multiple behavioral criteria. Psychol. Rev. 1974, 81, 59-74. [CrossRef]

49. Singh, S.; Sahni, M.M.; Kovid, R.K. What drives FinTech adoption? A multi-method evaluation using an adapted technology acceptance model. Manag. Decis. 2020, 58, 1675-1697. [CrossRef]

50. Lai, Y.-H.; Huang, H.-C.; Chang, C.-M.; Chun, S.-Y. Affecting Taiwanese College Students' Digital Music Download Behavioral Intention: An Empirical Study. Res. J. Appl. Sci. Eng. Technol. 2013, 6, 2118-2121. [CrossRef]

51. Shah Alam, S.; Fauzi Mohd Jani, M.; Asiah Omar, N.; Hossain, T.; Ahsan, M.N. Empirical Study of Theory of Reason Action (TRA) Model for ICT Adoption among the Malay Based SMEs in Malaysia. Bus. Manag. Strategy 2012, 3, 43-53. [CrossRef]

52. Palau-Saumell, R.; Forgas-Coll, S.; Sánchez-García, J.; Robres, E. User Acceptance of Mobile Apps for Restaurants: An Expanded and Extended UTAUT-2. Sustainability 2019, 11, 1210. [CrossRef]

53. Khan, I.U.; Hameed, Z.; Khan, S.U. Understanding online banking adoption in a developing country: UTAUT2 with cultural moderators. J. Glob. Inf. Manag. 2017, 25, 23. [CrossRef]

54. Chang, C.M.; Liu, L.W.; Huang, H.C.; Hsieh, H.H. Factors influencing Online Hotel Booking: Extending UTAUT2 with age, gender, and experience as moderators. Information 2019, 10, 281. [CrossRef]

55. Zeba, F.; Shaheen, M.; Krishnankutty, R. Hedonic and utilitarian values behind engagement of online consumers. J. Electron. Commer. Organ. 2020, 18, 1-20. [CrossRef]

56. Escobar-Rodríguez, T.; Carvajal-Trujillo, E. Online purchasing tickets for low cost carriers: An application of the unified theory of acceptance and use of technology (UTAUT) model. Tour. Manag. 2014, 43, 70-88. [CrossRef]

57. Savage, M.W.; Tokunaga, R.S. Moving toward a theory: Testing an integrated model of cyberbullying perpetration, aggression, social skills, and Internet self-efficacy. Comput. Hum. Behav. 2017, 71. [CrossRef]

58. Foroughi, B.; Iranmanesh, M.; Hyun, S.S. Understanding the determinants of mobile banking continuance usage intention. J. Enterp. Inf. Manag. 2019, 32, 1015-1033. [CrossRef]

59. Lee, E.Y.; Lee, S.B.; Jeon, Y.J.J. Factors influencing the behavioral intention to use food delivery apps. Soc. Behav. Personal. 2017, 45, 1461-1474. [CrossRef]

60. Morosan, C. Theoretical and empirical considerations of guests' perceptions of biometric systems in hotels: Extending the technology acceptance model. J. Hosp. Tour. Res. 2012, 35, 52-84. [CrossRef]

61. Shin, D.H. Modeling the interaction of users and mobile payment system: Conceptual framework. Int. J. Hum. Comput. Interact. 2010, 26, 917-940. [CrossRef]

62. de Kerviler, G.; Demoulin, N.T.M.; Zidda, P. Adoption of in-store mobile payment: Are perceived risk and convenience the only drivers? J. Retail. Consum. Serv. 2016, 31, 334-344. [CrossRef]

63. Martins, C.; Oliveira, T.; Popovič, A. Understanding the internet banking adoption: A unified theory of acceptance and use of technology and perceived risk application. Int. J. Inf. Manag. 2014, 34, 1-13. [CrossRef]

64. Lam, S.Y.; Shankar, V. Asymmetries in the effects of drivers of brand loyalty between early and late adopters and across technology generations. J. Interact. Mark. 2014, 28, 26-42. [CrossRef]

65. Ryu, H.S. What makes users willing or hesitant to use FinTech?: The moderating effect of user type. Ind. Manag. Data Syst. 2018, 118, 541-569. [CrossRef]

66. Morosan, C.; DeFranco, A. It's about time: Revisiting UTAUT2 to examine consumers' intentions to use NFC mobile payments in hotels. Int. J. Hosp. Manag. 2016, 53, 17-29. [CrossRef]

67. Najib, M.; Kiminami, A. Competitive strategy and business performance of small and medium enterprises in the indonesian food processing industry. Stud. Reg. Sci. 2011, 41, 315-330. [CrossRef]

68. Chin, W.W.; Newsted, P.R. Structural equation modeling analysis with small samples using partial least squares. In Statistical Strategies for Small Sample Research; Hoyle, R.H., Ed.; Sage Publications: Thousand Oaks, CA, USA, 1999; pp. $307-341$. 
69. Huang, Z.; Benyoucef, M. User preferences of social features on social commerce websites: An empirical study. Technol. Forecast. Soc. Chang. 2015, 95, 57-72. [CrossRef]

70. Chen, K.H.; Wang, C.H.; Huang, S.Z.; Shen, G.C. Service innovation and new product performance: The influence of marketlinking capabilities and market turbulence. Int. J. Prod. Econ. 2016, 172, 54-64. [CrossRef]

71. Chesbrough, H.W. The era of open innovation. Mit Sloan Manag. Rev. 2003, 44, 35-41.

72. Sarkar, S.; Costa, A.I.A. Dynamics of open innovation in the food industry. Trends Food Sci. Technol. 2008, 19, 574-580. [CrossRef]

73. Costa, A.I.A.; Jongen, W.M.F. New insights into consumerled food product development. Trends Food Sci. Technol. 2006, 17, 457-465. [CrossRef]

74. Aguilera, J.M. Seligman Lecture 2005: Food product engineering: Building the right structures. J. Sci. Food Agric. 2006, 86, 1147-1155. [CrossRef]

75. Bigliardi, B.; Galati, F. Models of adoption of open innovation within the food industry. Trends Food Sci. Technol. 2013, 30, 16-26. [CrossRef]

76. Mosteanu, N.R.; Faccia, A. FinTech Frontiers in Quantum Computing, Fractals, and Blockchain Distributed Ledger: Paradigm Shifts and Open Innovation. J. Open Innov. Technol. Mark. Complex. 2021, 7, 19. [CrossRef] 